\title{
Treatment Selection for a Vesicoureteral Reflux Case Following Renal Transplantation
}

\author{
Böbrek Nakli Sonrası Gelișen Vezikoüreteral Reflü Olgusunda Tedavi Seçimi
}

\author{
Mehmet Erikoğlu', Halil Ibrahim Tașcl' ${ }^{2}$, Mehmet Balasar ${ }^{3}$, Mesut Pișkin ${ }^{3}$ \\ ${ }^{1}$ Department of General Surgery, Necmettin Erbakan University Meram Medical Faculty, Konya, Turkey; ${ }^{2}$ Clinic of General Surgery, \\ Turkish Ministry of Health Reyhanlı Public Hospital, Hatay, Turkey; ${ }^{3}$ Department of Urology, Necmettin Erbakan University Meram \\ Medical Faculty, Konya, Turkey
}

\begin{abstract}
The vast majority of renal transplant patients suffer from urological complications. These urological complications account for the most important causes of morbidity and mortality cases such as delay in graft functions and graft loss following transplantation.57-year-old male patient contracted vesicoureteral reflux (VUR) following cadaveric renal transplantation. Initially subureteric injection was tried because of recurrent urinary tract infection and impairment of graft functions but open procedure ureteroneocystostomy was repeated since the injection failed to produce results. The patient is currently in his post-op month 10 and his follow-ups revealed no problems thus far.While less invasive methods such as endoscopic procedures can primarily be selected for the treatment of VUR, which leads to urinary tract infections and impairment in graft functions subsequently, open surgical procedures are considered to be an appropriate approach for failed injection or advanced stage cases.
\end{abstract}

Key words: renal transplantation; subureteric injection; vesicoureteral reflux

\section{ÖZET}

Böbrek nakli yapılmıș hastaların önemli bir kısmında ürolojik komplikasyonlar gelișmektedir. Gelișen bu ürolojik komplikasyonlar nakil sonrası greft fonksiyonunda gecikme, greft kaybı gibi morbiditelerin ve mortalitenin en önemli sebeplerindendir. Elli yedi yașında erkek hastada kadaverik böbrek nakli sonrasında vezikoüreteral reflü geliști. Tekrarlayan idrar yolu enfeksiyonu ve greft fonksiyonlarında bozulmaya yol açması nedeni ile öncelikle subüreterik enjeksiyon denedi; fakat bașarıı olmaması üzerine açık prosedürle üreteroneosistostomi ișlemi tekrarlandı. Hasta ameliyat sonrası 10. ayında ve takipleri problemsiz olarak devam ediyor. Sonuçta idrar yolu enfeksiyonu ve greft fonksiyonlarında bozulmaya yol açan VUR sonrasında öncelikle daha az invazif bir yöntem olan endoskopik yöntemler tercih edilebilirken, bașarısız enjeksiyon; ya da ileri evre vakalarda açık cerrahi prosedürün tercih edilmesi uygun bir yaklașım olarak görülmektedir.

Anahtar kelimeler: böbrek nakli, subüreterik enjeksiyon, vezikoüreteral reflü

Uzm. Dr. Halil İbrabim Tasct, TC Sağlık Bakanliğı Reyhanlı Devlet Hastanesi, Genel Cerrabi Kliniği, Reyhanl, Hatay - Türkiye, Tel. 05054810445

Email.okcu1@mynet.com

Gelis Taribi:29.04.2015 • Kabul Taribi:02.11.2015

\section{Introduction}

The 5-year survival rate for renal transplant patients is significantly higher than that of dialysis patients $(85.5 \% \text { and } 35.8 \% \text { respectively })^{1}$. Although renal transplantation has such positive sides as cost-efficiency and high survival rates, a vast majority of renal transplant patients contract urological complications. These urological complications account for the most important causes of morbidity and mortality cases such as delay in graft functions and graft loss following transplantation ${ }^{2}$. The most significant of these complications are urinary leakage, narrowness, and vesicoureteral reflux.

Our aim in this case report is to present the case of a patient that received endoscopic subureteral injection for the treatment of vesicoureteral reflux following renal transplantation but had to go through ureteroneocystostomy again since the injection failed to produce results in the light of literature on the subject.

\section{Case Report}

Fifty-seven-year-old male patient, who had been in hemodialysis for the last 8 years because of chronic renal failure brought about by diabetes and hypertension, underwent cadaveric renal transplantation. Lich-Gregoir method was performed for ureterovesical anastomosis during the surgery. Urinary output was enabled following surgery. A drop in urea and creatinine values was seen. Early examinations revealed no pathologies in the transplanted kidney's blood build-up, excretion, and concentration functions. The patient was discharged on day 15 without any problems. 


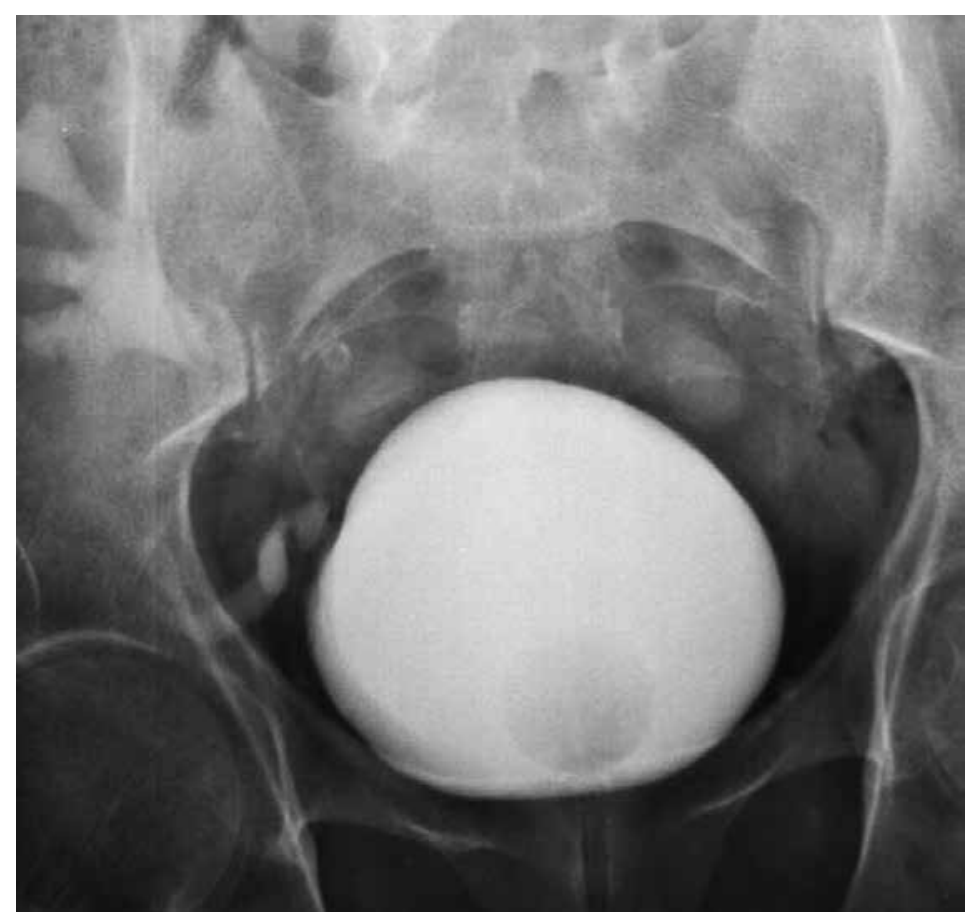

Figure 1. Voiding cystourethrographic view of recurrent reflux after subureteral injections.

The patient, who had burning sensation when urinating, was seen to have urinary tract infection in the first post-op month during the follow-ups. Escherichia and klebsiella pneumonia as seen in the urine culture. The patient's problem frequently recurred and he had secondary renal function impairment brought about by urinary tract infection. In his laboratory, creatinin value was 2,2 mg/dL, üre 98: mg/dL, white blood cell:3400. Upon the patient's voiding cystourethrography revealed that there was vesicoureteral reflux (VUR) in the transplanted kidney, the urology clinic administrated subureteric Dextranomer / hyaluronic acid copolymer (Deflux) injection to the patient. Patient's complaints continued and no progress was seen in his current pathology as revealed by his laboratory and radiological results at the end of the first month following this procedure (Fig. 1). Reoperation was planned and during operation ureter of transplanted kidney was seen as dilated and tortuous. Open procedure ureteroneocystostomy was repeated accorrding to the Lich-Gregoir technique. The patient's routine followups continue to be performed and his examinations and analyses revealed neither urinary tract infection nor any finding that would be suggestive of VUR in the post-op month 10 and his renal functions were within normal on bounds. As there were no evidence of a urinary tract infection or renal failure due to laboratory results, urine culture and ultrasonograph, voiding cystourethrography was not repeated after second operation to avoid contrast nephropathy.

\section{Discussion}

Although renal transplantation plays a positive role in maintaining cost-efficiency and survival, a significant portion of renal transplant patients develop urological complications. These complications give way to an increase in morbidity rates and subsequently an increase in graft loss in patients ${ }^{2}$. According to the data presented in literature, the rate of post-renal transplantation complications like leakage, narrowness, and VUR varies between $2.5 \%$ and $14.1 \%{ }^{3}$. In our case, the patient, who had recurrent urinary tract infection following renal transplantation, we determined VUR as revealed by examinations and analyses.

One of the most significant reasons for these problems relies both on organ removal and technical problems faced during preparation and ureteral anastomosis ${ }^{4}$. In a study by Gürkan et al. the authors compared two ureteral anastomoses techniques and stated that VUR was seen in 3 out of 34 cases in which the Lich Gregoir technique was used, while no VUR cases were seen 
in 41 cases that had undergone ureteroureterostomy ${ }^{5}$. The results of this study suggest that ureteroureterostomy should be performed as the type of anastomosis in patients with no VUR in the native kidneys. The initial operation for our patient was also the Lich Gregoir technique used in ureteral anastomosis. We think that VUR, which was developed in our patient, related with technical problems faced during first operation.

Post-transplantation VUR rate varies between $50 \%$ and $86 \%$ depending on the technique of ureteroneocystostomy ${ }^{6}$. In most of the studies the cases with VUR are mostly early stage, while stages 4 and 5 are not seen. There are many studies which have shown that in early stage VUR cases, or even in advanced stage VUR as presented in some studies, the rate of urinary tract infection and the rate of related urosepsis did not change in comparison to control groups 7 . In spite of the presence of these data, most of the clinicians are in consensus that advanced stage VUR cases with urosepsis based on recurrent urinary tract infection or urinary tract infection should be surgically treated ${ }^{8}$. Intervention was planned for our case upon frequent urinary tract infection and related impairment in graft functions.

Endoscopic treatment methods came to the fore since a second open surgical procedure would be an invasive method and the risk of ureteral necrosis, urinary leakage, and narrowness at the anastomosis. It is preferred over subureteric injection open surgery because it has a low rate of post-op morbidity, shorter period of procedure and hospitalization, and it does not give way to any problems in dissection during a possible operation following failed injection ${ }^{9}$. Materials like teflon, dextranomer in sodium hyaluronate, calcium hydroxyapatite, pyrolytic carbon coated xirconium oxide were used in suburetic injection ${ }^{9}$. Although the results of suburetic injection are similar to those of open surgery in lowgrade VUR cases, success rates go down with advanced stage cases and after repeated injections ${ }^{9}$. We initially administered suburetic injection in our patient because it was a method with less morbidity but since it failed we performed open surgical procedure.
Consequently, ureteral anastomosis technique used during renal transplantation proves to be an important factor for VUR alongside with other post-operative urological complications. While endoscopic methods that are less invasive can be primarily selected to treat VUR cases, which causes urinary tract infection and impairment in graft functions, to prefer open surgical procedures after failed injection or in advanced cases is considered to be an appropriate approach.

\section{References}

1. National Kidney and Urologic Diseases Information Clearinghouse, KidneyDisease Statistics for theUnited States, Publication No 12-3895, National Institutes of Health, Washington, DC, USA, 2012.

2. Beyga ZT, Kahan BD. Surgical complications of kidney transplantation. J Nephrol 1998;11:137-5.

3. Li Marzi V, Filocamo MT, Dattolo E, et al. The treatment of fistulae and ureteral steno-sis after kidney transplantation. Transplant Proc 2005; 37: 2516-7.

4. Kumar A, Verma BS, Srivastava A, et al. Eval-uation of the urological complications of living related renal transplantation at a single center during the last 10 years: impact of the double J stent. J Urol 2000; 164: 657-60.

5. Gurkan A, Yakupoglu Y, Dinckan A, et al. Comparing two ureteral reimplantation techniques in kidney transplant recipients. Transpl Int 2006:802-6.

6. M. Ostrowski, Z. Włodarczyk, T. Wesołowski et al. "Influence of ureterovesical anastomosis technique on the incidence of vesicoureteral reflux in renal transplant recipients. Ann Transplant 1999;4:54-8.

7. Favi E, Spagnoletti G, Valentini A et al. Long-term clinical impact of vesicoureteral reflux in kidney transplantation. Transplant Proc 2009;41:1218-20.

8. Duty B, Conlin M, Fuchs E, Barry J. The Current Role of Endourologic Management of Renal Transplantation Complications. Adv Urol 2013;2013:1-6.

9. Pirinççi N, Geçit İ, Güneş $M$, et al. Endoskopik Vezikoüreteral Reflü Tedavisi Sonuçlarımız. Van Tıp Dergisi 2011;18(4):201-4. 